\title{
Effect of Nitrogen On Growth and Yield of Chili (Capsicum annuum L.) in Roof Top Garden
}

\author{
Khalid Mahmud $^{1, a, *}$, Taslim Hossain ${ }^{2, b}$, Tamanna Haque Mou ${ }^{3, c}$, Asraf Ali ${ }^{1, d}$, Monirul Islam ${ }^{1, e}$ \\ ${ }^{1}$ Sher-e-Bangla Agricultural University, Bangladesh \\ ${ }^{2}$ Bangladesh Agricultural University, Bangladesh \\ ${ }^{3}$ Agrotechnology Descipline, Khulna University, Bangladesh \\ *Corresponding author
}

A R T I C L E I N F O
Research Article
Received : 18/06/2019
Accepted : 03/12/2019

A B S T R A C T

The present study was carried out to evaluate the effect of nitrogen on growth and yield of chili (Capsicum annuum L.) under rooftop conditions. The single factorial experiments were laid out in Randomized Complete Block Design (RCBD) with three replications. Four levels of nitrogen $\mathrm{N}_{0}: 0$ $\mathrm{kg} \mathrm{N} \mathrm{ha}^{-1}, \mathrm{~N}_{1}: 90 \mathrm{~kg} \mathrm{~N} \mathrm{ha}^{-1}, \mathrm{~N}_{2}: 110 \mathrm{~kg} \mathrm{~N} \mathrm{ha}^{-1}$ and $\mathrm{N}_{3}: 130 \mathrm{~kg} \mathrm{~N}^{-1}$ were used in this experiment. Growth and yield contributing parameters significantly influenced by different doses of nitrogenous fertilizers. The dose of $\mathrm{N}_{2}$ gave the highest plant height $(80.97 \mathrm{~cm})$ and most of the morphological parameters increased with increasing nitrogen levels up to $\mathrm{N}_{2}$. The treatment $\mathrm{N}_{3}$ gave the highest fruit length $(4.93 \mathrm{~cm})$, yield of fruits plant- ${ }^{-1}(165.33 \mathrm{gm})$, average fruit yield plot$^{-1}(0.66 \mathrm{~kg})$, individual fruit weight $(1.97 \mathrm{~g})$ and average fruit yield $\left(5.533 \mathrm{kgha}^{-1}\right)$. Based on the present results,

Keywords:

Chili it can be suggested that use of $130 \mathrm{~kg} \mathrm{~N} \mathrm{ha}^{-1}$ increased plant growth and fruit yield of chili in rooftop

Roof top garden

Organic fertilizer

Nitrogen

Capsicum annuum garden. b@taslimmisha.420@gmail.com
d@ashraf.ku11@gmail.com

(iD https://orcid.org/0000-0001-7450-8251 (iD) https://orcid.org/0000-0002-6886-9621

\section{Introduction}

Nowadays, 54 percent population of the planet are living in urban area and the share is expected to increase to 70 percent by 2050 . Due to act of rapid urbanization and urban growth is placing massive demand on urban food supply systems. Moreover, many cities in the world facing food crisis, decrease green space and increase heat effects. In that case, urban agriculture is promoted as a possible solution to reduce the effect of this problems (Smit et al., 2001).

Dhaka is one of the world's fasted growing mega cities and open cultivable land has been converting to build area indiscriminately and the agricultural field decreased at an alarming rate (Islam and Ahmed, 2011). Rooftop farming can be a possible solution to reduce the food problems, make the urban area more self-sufficient and make fresh vegetables more accessible to the urban locality (Wardard, 2014). A recent survey showed that most of the roofs of Dhaka city are suitable for gardening which don't require major improvement but also need some modifications (Islam, 2004). In Bangladesh, chili (Capsicum annuum L.) is one of the most important vegetables crops which needs in every cooking process. Due to practice of chili production on rooftop garden chili production will be increased which meet the demand of urban people and also reduce the costs of transport as well as encourage the verities of vegetables production in the urban area (Rhodes et al., 2000).

The Solanaceous group of vegetables (chili) generally takes up large amounts of nutrients that have specialized functions and should be supplied to plant at the right time with suitable quantity. When chilies are adequately supplied with the essential nutrients through fertilization it improves their yield, quality and enhance maturity. Generally, a large amount of nitrogen is required for the growth of the leaf and stem of chili. It plays a vital role as a constituent of protein, nucleic acid and chlorophyll. Nitrogen progressively 
increases the marketable yield but an adequate supply of nitrogen is essential for vegetative growth, and desirable yield (Aminifard et al., 2012). Rooftop farmers should also be especially careful of applying various doses of nitrogen and phosphorus fertilizers will be used and optimum dose that is beneficial for chili production in rooftop will be identified (Khurana et al., 2006). Considering the above mentioned facts this experiment will satisfy the following objectives: 1) To find out the optimum dose of nitrogen for growth and development of Chili in rooftop garden; 2) To study the effect of nitrogen and for obtaining desirable yield of chili in rooftop.

\section{Materials and Methods}

\section{Experimental Site and Soil Condition}

The experiment was conducted at the roof of third floor of Biotechnology department of Sher-e-Bangla Agricultural University, Sher-e-Bangla Nagar,Dhaka, Bangladesh. The duration of the experiment was October, 2016 to March, 2017. The experimental area was under the sub-tropical monsoon climate, which is characterized by heavy rainfall during summer season and scanty in the winter season (October to March). The average maximum temperature during the period of experiment was $29.35^{\circ} \mathrm{C}$ and the average minimum temperature was $15.10^{\circ} \mathrm{C}$. The soil of the experimental site was collected from outside of Dhaka city which was sandy clay.

\section{Land Preparation}

The 30 days old seedling winter chili were collected from BARI, Joydebpur, Gazipur. The experiment was laid out in Randomized Complete Block Design (RCBD) having single factors with three replications. An area of 9 $\mathrm{m} \times 4 \mathrm{~m}$ was divided into three equal blocks. Each block was consists of 6 plots where treatments are allotted. There were 24 unit plots in the experiment. The size of each plot was $1 \mathrm{~m} \times 1 \mathrm{~m}$, which accommodated 4 plants at a spacing $0.3 \mathrm{~m} \times 0.3 \mathrm{~m}$. The distance between two blocks and two plots were kept $0.5 \mathrm{~m}$ and $0.25 \mathrm{~m}$ respectively. The doses and application method of fertilizers were given in Table 1.

\section{Collection of Data}

All four plants were selected from plot for data collection. Data on the following parameters were recorded from the sample plants during the course of experiment. The data on pant height, number of leaves per plant, leaf length of plant, leaf breadth of plant, number of branches per plant, length of fruit, diameter of fruit, length of pedicel, individual fruit weight, yield of fruits per plant, yield of fruits per plot and yield of fruits per hectare were recorded.
$\mathrm{FYH}=\frac{\text { Fruit yield per plot }(\mathrm{kg}) \times 10000\left(\mathrm{~m}^{2}\right)}{\text { Area of plot in square meter }\left(\mathrm{m}^{2}\right) \times 1000(\mathrm{~kg})}$

FYH: Fruit yield (ton) per hectare

\section{Statistical Analysis}

The data obtained from different yield components and yields were statistically analyzed for analysis of variance using the MSTAT-C statistical package program to find out the significance of the difference among the treatments and their combinations. The analysis was performed by Fvariance test, and the significance of the difference between pairs of treatment means was evaluated by the Duncan's Multiple Range Test (DMRT) at 5\% and 1\% levels of probability (Gomez and Gomez, 1984).

\section{Results}

\section{Effect of Treatment On Morphological Characteristics} of Capsicum annum

The result revealed that at 30 DAT the tallest plant was recorded from $\mathrm{N}_{2}(39.10 \mathrm{~cm})$ which was statistically similar with $\mathrm{N}_{1}(38.03 \mathrm{~cm})$ and $\mathrm{N}_{3}(35.87 \mathrm{~cm})$ whereas the shortest plant height was found from $\mathrm{N}_{0}(23.00 \mathrm{~cm})$. At 45 DAT the highest plant height $(57.00 \mathrm{~cm})$ was observed from the $\mathrm{N}_{2}$ treatment which was statistically similar to $\mathrm{N}_{3}(54.30 \mathrm{~cm})$ and $\mathrm{N}_{1}(51.77 \mathrm{~cm})$ whereas, the lowest $(33.33 \mathrm{~cm})$ was observed in $\mathrm{N}_{0}$ treatment. At 65 DAT the highest plant height (68.27 $\mathrm{cm})$ was observed from the $\mathrm{N}_{1}$ treatment which was statistically similar to $\mathrm{N}_{2}(68.23 \mathrm{~cm})$ and $\mathrm{N}_{3}(67.00)$ whereas, the lowest $(45.67 \mathrm{~cm})$ was observed from $\mathrm{N}_{0}$ treatment. At 75 DAT the highest plant height $(80.967 \mathrm{~cm})$ was observed from the $\mathrm{N}_{2}$ treatment which was statistically similar with $\mathrm{N}_{1}(76.60$ $\mathrm{cm}), \mathrm{N}_{3}(79.73 \mathrm{~cm})$ whereas, the lowest $(51.83 \mathrm{~cm})$ was observed from $\mathrm{N}_{0}$ treatment (Table 2).

At 30 DAT the highest number of leaves per plant (57.33) was observed from the $\mathrm{N}_{2}$ treatment which was statistically similar to $\mathrm{N}_{1}$ (53.33) and $\mathrm{N}_{3}$ (52.67) whereas the lowest (34.33) was observed from $\mathrm{N}_{0}$ treatment. At 45 DAT the highest number of leaves per plant (96.33) was observed from the $\mathrm{N}_{2}$ treatment whereas the lowest (67.33) was observed from $\mathrm{N}_{0}$ treatment. At 60 DAT the highest number of leaves per plant was observed from the $\mathrm{N}_{2}$ (144.00) treatment whereas the lowest was observed from $\mathrm{N}_{0}$ (84.33) treatment. At 75 DAT the highest number of leaves per plant was observed from the $\mathrm{N}_{1}$ (181.33) treatment which was statistically similar to $\mathrm{N}_{2}$ (175.33) whereas the lowest was observed from $\mathrm{N}_{0}$ (119.33) treatment (Table 3).

Table 1. Manures and fertilizers application method on chilli field

\begin{tabular}{l|rrrrr}
\hline \multirow{2}{*}{ Name of manure and fertilizers } & \multirow{2}{*}{ Doses/ha } & \multicolumn{4}{c}{ Application (\%) } \\
\cline { 3 - 6 } & & Basal & 25 DAT & 50 DAT & 75 DAT \\
\hline Cowdung & $10 \mathrm{ton}$ & 100 & - & - & - \\
Urea $\left(\mathrm{N}_{0}\right)$ & $0 \mathrm{~kg}$ & 0 & 0 & 0 & 0 \\
Urea $\left(\mathrm{N}_{1}\right)$ & $90 \mathrm{~kg}$ & 45 & 16.67 & 16.67 & 16.67 \\
Urea $\left(\mathrm{N}_{2}\right)$ & $110 \mathrm{~kg}$ & 55 & 16.67 & 16.67 & 16.67 \\
Urea $\left(\mathrm{N}_{3}\right)$ & $130 \mathrm{~kg}$ & 65 & 16.67 & 16.67 & 16.67 \\
TSP & $80 \mathrm{~kg}$ & 100 & - & - & - \\
MoP & $50 \mathrm{~kg}$ & 100 & - & - & - \\
\hline DAT
\end{tabular}


Table 2. The effect of different levels of nitrogen on plant height of chili

\begin{tabular}{l|cccc}
\hline \multirow{2}{*}{ Treatment } & \multicolumn{4}{c}{ Plant Height $(\mathrm{cm})$} \\
\cline { 2 - 5 } & 30 DAT & 45 DAT & 60 DAT & 75 DAT \\
\hline $\mathrm{N}_{0}$ & $23.00^{\mathrm{b}}$ & $33.33^{\mathrm{b}}$ & $45.67^{\mathrm{b}}$ & $51.83^{\mathrm{b}}$ \\
$\mathrm{N}_{1}$ & $38.03^{\mathrm{a}}$ & $51.77^{\mathrm{a}}$ & $68.27^{\mathrm{a}}$ & $76.60^{\mathrm{a}}$ \\
$\mathrm{N}_{2}$ & $39.10^{\mathrm{a}}$ & $57.00^{\mathrm{a}}$ & $68.23^{\mathrm{a}}$ & $80.97^{\mathrm{a}}$ \\
$\mathrm{N}_{3}$ & $35.87^{\mathrm{a}}$ & $54.30^{\mathrm{a}}$ & $67.00^{\mathrm{a}}$ & $79.73^{\mathrm{a}}$ \\
Level of Significance & $*$ & $*$ & $*$ & $*$ \\
LSD (0.01) & 5.47 & 6.96 & 16.87 & 11.21 \\
CV\% & $5.92 \%$ & $10.33 \%$ & $6.06 \%$ & $6.87 \%$ \\
\hline
\end{tabular}

$\mathrm{N}_{0}: 0 \mathrm{~kg} \mathrm{~N} \mathrm{ha-}{ }^{1}$ (control); $\mathrm{N}_{1}: 90 \mathrm{~kg} \mathrm{~N}$ ha- ${ }^{1} ; \mathrm{N}_{2}: 110 \mathrm{~kg} \mathrm{~N}$ ha- ${ }^{1} ; \mathrm{N}_{3}: 130 \mathrm{~kg} \mathrm{~N} \mathrm{ha-}{ }^{1}, *=5 \%$ Level of Significance, $* *=1 \%$ Level of Significance, NS= Non Significance

Table 3. The effect of different levels of nitrogen on number of leaves plant ${ }^{-1}$ of chili

\begin{tabular}{l|cccc}
\hline \multirow{2}{*}{ Treatment } & \multicolumn{4}{|c}{ Number of Leaves Plant-1 } \\
\cline { 2 - 5 } & 30 DAT & 45 DAT & 60 DAT & 75 DAT \\
\hline $\mathrm{N}_{0}$ & $34.33^{\mathrm{b}}$ & $67.33^{\mathrm{b}}$ & $84.33^{\mathrm{b}}$ & $119.33^{\mathrm{b}}$ \\
$\mathrm{N}_{1}$ & $53.33^{\mathrm{a}}$ & $90.00^{\mathrm{a}}$ & $129.67^{\mathrm{a}}$ & $181.33^{\mathrm{a}}$ \\
$\mathrm{N}_{2}$ & $57.33^{\mathrm{a}}$ & $96.33^{\mathrm{a}}$ & $144.00^{\mathrm{a}}$ & $175.33^{\mathrm{a}}$ \\
$\mathrm{N}_{3}$ & $52.67^{\mathrm{a}}$ & $96.00^{\mathrm{a}}$ & $139.33^{\mathrm{a}}$ & $170.00^{\mathrm{a}}$ \\
Level of Significance & $*$ & $\mathrm{NS}$ & $*$ & $*$ \\
LSD (0.01) & 7.90 & 14.95 & 7.67 & 25.27 \\
$\mathrm{CV} \%$ & $6.10 \%$ & $6.52 \%$ & $2.35 \%$ & $5.97 \%$ \\
\hline
\end{tabular}

$\mathrm{N}_{0}: 0 \mathrm{~kg} \mathrm{~N} \mathrm{ha-}{ }^{-1}$ (control); $\mathrm{N}_{1}: 90 \mathrm{~kg} \mathrm{~N}$ ha- ${ }^{-1} ; \mathrm{N}_{2}: 110 \mathrm{~kg} \mathrm{~N}{ }^{-1} ; \mathrm{N}_{3}: 130 \mathrm{~kg} \mathrm{~N} \mathrm{ha-}{ }^{-1}, *=5 \%$ Level of Significance, $* *=1 \%$ Level of Significance, $\mathrm{NS}=$ Non Significance

Table 4. The effect of different levels of nitrogen on morphological characteristics of chili

\begin{tabular}{l|ccc}
\hline \multicolumn{1}{c|}{ Treatment } & Leaf Length $(\mathrm{cm})$ & Leaf Breadth $(\mathrm{cm})$ & Number of Branches Plant- $^{1}$ \\
\hline Levels of Nitrogen & & & $7.13^{\mathrm{b}}$ \\
N0 & $10.47^{\mathrm{a}}$ & $3.00^{\mathrm{b}}$ & $12.67^{\mathrm{a}}$ \\
N1 & $10.80^{\mathrm{a}}$ & $3.17^{\mathrm{ab}}$ & $13.33^{\mathrm{a}}$ \\
N2 & $11.80^{\mathrm{a}}$ & $3.83^{\mathrm{a}}$ & $12.67^{\mathrm{a}}$ \\
N3 & $11.57^{\mathrm{a}}$ & $3.53^{\mathrm{ab}}$ & $\mathrm{NS}$ \\
Level of Significance & $\mathrm{NS}$ & $*$ & 6.54 \\
LSD (0.01) & 2.79 & 0.76 & $21.23 \%$ \\
CV\% & $10.46 \%$ & $8.52 \%$ & \\
\hline
\end{tabular}

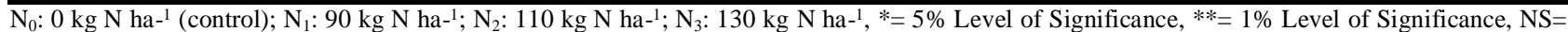
Non Significance

The longest length of leaf $(11.80 \mathrm{~cm})$ was observed from $\mathrm{N}_{2}$ while the shortest length of leaf $(10.46 \mathrm{~cm})$ was found from $\mathrm{N}_{0}$ or control treatment (Table 4). The highest leaf breadth $(3.88 \mathrm{~cm})$ was observed from $\mathrm{N}_{2}$ which was statistically identical to $\mathrm{N}_{3}(3.53 \mathrm{~cm})$ while the shortest leaf breadth $(3.00 \mathrm{~cm})$ was found from $\mathrm{N}_{0}$ or control condition (Table 4). The maximum number of branches (13.33) was observed from $\mathrm{N}_{2}$ and the minimum number of branches was recorded from $\mathrm{N}_{0}$ (9.13) or control condition (Table 4).

Effect of Different Levels of Nitrogen on Yield Contributing Characteristics of Chili

Fruit length was recorded $3.87 \mathrm{~cm}, 4.47 \mathrm{~cm}, 4.73 \mathrm{~cm}$ and $4.93 \mathrm{~cm}$ in $\mathrm{N}_{0}, \mathrm{~N}_{1}, \mathrm{~N}_{3}$ and $\mathrm{N}_{2}$ treatments respectively. Maximum $(4.93 \mathrm{~cm})$ fruit length was found in $\mathrm{N}_{3}$ treatment which was statistically similar to $\mathrm{N}_{2}(4.73 \mathrm{~cm})$ and $\mathrm{N}_{1}(4.47$ $\mathrm{cm})$ treatment whereas minimum fruit length was recorded from $\mathrm{N}_{0}(3.87 \mathrm{~cm})$ or control treatment (Table 5). Fruit diameter was recorded $0.66,0.74,0.78$ and $0.71 \mathrm{~cm}$ in $\mathrm{N}_{0}$, $\mathrm{N}_{1}, \mathrm{~N}_{3}$ and $\mathrm{N}_{2}$ treatments respectively. Maximum $(0.78$ $\mathrm{cm}$ ) fruit diameter was found in $\mathrm{N}_{2}$ treatment which was statistically similar to $\mathrm{N}_{1}(0.74 \mathrm{~cm})$ treatment whereas minimum fruit diameter was recorded in $\mathrm{N}_{0}(0.66 \mathrm{~cm})$ or control treatment (Table 5).
Individual fruit weight was recorded 1.26, 1.77, 1.88 and $1.97 \mathrm{~g}$ in $\mathrm{N}_{0}, \mathrm{~N}_{1}, \mathrm{~N}_{2}$ and $\mathrm{N}_{3}$ treatments respectively. Highest individual fruit weight $(1.97 \mathrm{~g})$ was found in $\mathrm{N}_{3}$ treatment whereas the lowest individual fruit weight was found in $\mathrm{N}_{0}$ (1.26 g) or control treatment. The result showed increase in nitrogen levels increases the fruit weight (Table 6). Highest number of fruits per plant was found in $\mathrm{N}_{3}$ (165.33) treatment whereas lowest number of fruits per plant was found in $\mathrm{N}_{0}$ (82.67) or control treatment. It was revealed that at optimum level nitrogen fertilizer gave highest yield plant $^{-1}$ and increase nitrogen fertilization delayed flowering (Table 6). Yield of green fresh fruit of chilli was recorded $0.37,0.52,0.59$ and 0.66 kgplot $^{-1}$ in $\mathrm{N}_{0}, \mathrm{~N}_{1}, \mathrm{~N}_{2}$ and $\mathrm{N}_{3}$ treatments respectively (Table 6). Maximum (0.66 kgplot $\left.{ }^{-1}\right)$ yield was obtained in $\mathrm{N}_{3}$ treatment and minimum $\left(0.370 \mathrm{kgplot}^{-1}\right)$ was found in $\mathrm{N}_{0}$ treatment or control treatment (Table 6). Yield of green fresh fruit of chilli was recorded 3.7, 5.2, 5.9 and 6.6 tonha${ }^{1}$ in $\mathrm{N}_{0}, \mathrm{~N}_{1}, \mathrm{~N}_{2}$ and $\mathrm{N}_{3}$ treatments respectively (Table 6). Maximum (6.6 tonha ${ }^{-1}$ ) yield was obtained in $\mathrm{N}_{3}$ treatment and minimum (3.7 tonha ${ }^{-1}$ ) was found in $\mathrm{N}_{0}$ treatment or control treatment. Nitrogen fertilization improved plant growth, but did not influence fruiting time (Table 6). 
Table 5. The effect of different levels of nitrogen on yield contributing characteristics of chilli

\begin{tabular}{l|cc}
\hline \multicolumn{1}{c|}{ Treatment } & Fruit Length $(\mathrm{cm})$ & Fruit Diameter $(\mathrm{cm})$ \\
\hline $\mathrm{N}_{0}$ & $3.87^{\mathrm{c}}$ & $0.66^{\mathrm{a}}$ \\
$\mathrm{N}_{1}$ & $4.47^{\mathrm{b}}$ & $0.74^{\mathrm{a}}$ \\
$\mathrm{N}_{2}$ & $4.73^{\mathrm{ab}}$ & $0.78^{\mathrm{a}}$ \\
$\mathrm{N}_{3}$ & $4.93^{\mathrm{a}}$ & $0.71^{\mathrm{a}}$ \\
Level of Significance & $*$ & $\mathrm{NS}$ \\
LSD (0.01) & 0.42 & 0.17 \\
$\mathrm{CV} \%$ & $3.53 \%$ & $8.42 \%$ \\
\hline
\end{tabular}

$\mathrm{N}_{0}: 0 \mathrm{~kg} \mathrm{~N} \mathrm{ha}-{ }^{1}$ (control); $\mathrm{N}_{1}: 90 \mathrm{~kg} \mathrm{~N} \mathrm{ha}^{-1} ; \mathrm{N}_{2}: 110 \mathrm{~kg} \mathrm{~N}{ }^{-1} ; \mathrm{N}_{3}: 130 \mathrm{~kg} \mathrm{~N} \mathrm{ha}^{-1},{ }^{*}=5 \%$ Level of Significance, $* *=1 \%$ Level of Significance, NS= Non Significance

Table 6. The effect of different levels of nitrogen on yield contributing characteristics of chili

\begin{tabular}{l|cccc}
\hline \multicolumn{1}{c|}{ Treatment } & $\begin{array}{c}\text { Individual Fruit } \\
\text { Weight }(\mathrm{g})\end{array}$ & Yield Plant- $^{1}(\mathrm{~g})$ & Yield Plot- $^{1}(\mathrm{~kg})$ & Yield ha- $^{1}$ (ton) \\
\hline $\mathrm{N}_{0}$ & $1.26^{\mathrm{b}}$ & $82.67^{\mathrm{d}}$ & $0.37^{\mathrm{d}}$ & $3.7^{\mathrm{d}}$ \\
$\mathrm{N}_{1}$ & $1.77^{\mathrm{a}}$ & $130.00^{\mathrm{c}}$ & $0.52^{\mathrm{c}}$ & $5.2^{\mathrm{c}}$ \\
$\mathrm{N}_{2}$ & $1.88^{\mathrm{a}}$ & $149.33^{\mathrm{b}}$ & $0.59^{\mathrm{b}}$ & $5.9^{\mathrm{b}}$ \\
$\mathrm{N}_{3}$ & $1.97^{\mathrm{a}}$ & $165.33^{\mathrm{a}}$ & $0.66^{\mathrm{a}}$ & $6.6^{\mathrm{a}}$ \\
Level of Significance & $\mathrm{NS}$ & $* *$ & $* *$ & $* *$ \\
LSD (0.01) & 0.25 & 13.68 & 0.15 & 0.47 \\
$\mathrm{CV} \%$ & $5.55 \%$ & $3.88 \%$ & $3.86 \%$ & $4.01 \%$ \\
\hline
\end{tabular}

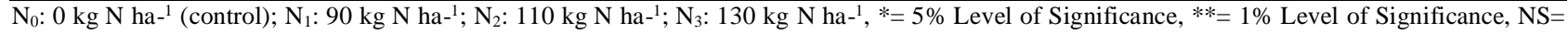
Non Significance

\section{Discussion}

Effect of Treatment on Morphological Characteristics of Capsicum annum

In roof top garden all morphological and yield contributing character were suppress due to the leaching of organic matter. The type of organic matter used will have a large influence on the amount of nutrients available, substrate biological activity and therefore also plant growth and performance (Nagase and Dunnett 2011). But the breakdown of organic matter can result in nutrient leaching which often decreases as the roof ages (Czemiel Berndtsson, 2010) which reduce the growth and development of chili plant at a higher extent. But in agricultural field condition, the nutrient loss was lower than roof top garden. That's why physical growth (plant height) of plant in roof top garden is lower than normal field condition.

The plant height of chilli was statistically significant with various levels $(30,45,60$ and 75 DAT) of nitrogen (Table 2). At 30, 45, 60 and 75 days after transplanting (DAT), the highest plant highest was observed from $\mathrm{N}_{2}$ treatment where $110 \mathrm{~kg} \mathrm{~N} \mathrm{ha}^{-1}$ urea was given. It was revealed that increased plant height up to a certain level then decreases due to increasing the nitrogen fertilizer. The result was similar with that of Lal and Pundrik (1971), Damke et al. (1990) and Nicola et al. (1995). They observed an improvement on plant height with increasing nitrogen application. Nitrogen fertilizer doses showed significant effect on number of leaves per plant of chilli at 30, 45, 60 and 75 DAT (Table 3). After every stage of transplanting of chili, $\mathrm{N}_{2}$ treatment was given highest number of leaves per plant. As data shown, nitrogen fertilization increased leaf number which were in agreement with findings of Ayodele (2002) and Boroujerdnia and Ansari (2007).

Leaf length and leaf breath of chilli was statistically influenced by different levels of nitrogen (Table 4). Leaf length, leaf breath and number of branches per plant were maximum in $110 \mathrm{~kg} \mathrm{~N} \mathrm{ha}^{-1}$ when applied. But number of branch per plant was decreased due to excess leaching of nitrogen and mulch materials were older. The increase in leaf area brought by the nitrogen supply causing expansion of individual leaves has also been reported by (Taylor et al., 1993). Nitrogen stimulated the cell division and cell expansion (Lemaire, 2001). A critical observation of the data indicated that leaf breadth increased with increasing levels of nitrogen up to $110 \mathrm{~kg} / \mathrm{ha}$ and then a decrease trend was observed with increase in nitrogen levels (Gupta and Sangar, 2000). Nitrogen has a significant effect on number of branches per plant as it activates vegetative growth. These results agree with the findings of Manchanda and Singh (1988). They concluded that branches per plant increase with the increasing nitrogen rate.

Effect of Different Levels of Nitrogen on Yield Contributing Characteristics of Capsicum annum

Besides the sun beating down on the roof, there is ambient heat being reflected from the roof surface, surrounding buildings, streetcars and metal exhaust and utility structures (Awal et al., 2010). The higher temperature greatly reduced the yield of chili because of the lack of moisture content in soil. But in agricultural field condition, the frequently irrigation facilitate to maintain the moisture content as well as maintain the soil temperature which increase the yield performance of chili.

For yield contributing characteristics, higher level of nitrogen needed for better production of chili. Significant variation was observed among the different treatments due to different doses of nitrogen in respect of average fruit length and fruit diameter of chilli (Table 5). For fruit length, $\mathrm{N}_{3}$ treatment $\left(130 \mathrm{~kg} \mathrm{~N} \mathrm{ha}{ }^{-1}\right)$ showed great performance whereas the highest fruit diameter was observed from $\mathrm{N}_{2}$ treatment $\left(110 \mathrm{~kg} \mathrm{~N} \mathrm{ha}^{-1}\right)$. The results are 
to some extent in agreement with Lal and Pundrik (1971) who observed an improvement in fruit size with increasing nitrogen application. In case of fruit length and diameter frequent irrigation were given in the roof due to reduce the evaporation loss of water and nutrient. Roy et al. (2011) documented the similar report on fruit diameter of chilli. According to them length and diameter of fruits and nos. fruits per plant increased significantly with increasing nitrogen dose at $\mathrm{N}_{3}$ treatment $\left(130 \mathrm{~kg} \mathrm{~N} \mathrm{ha}^{-1}\right)$.

There was a significant variation in single fruit weight and number of fruit per plant among different doses of nitrogen treatments (Table 6). Due to gradual increase of different doses the fruit weight and number of fruit per plant were increasing gradually. Data revelled that application of lower doses given lowest fruit weight $\left(\mathrm{N}_{1}\right.$ treatment). But when applying $\mathrm{N}_{3}$ treatment (130 $\mathrm{kg} \mathrm{N} \mathrm{ha}^{-1}$ ), the fruit weight was highest. The results also similar with Akanbi et al. (2007) who also reported that increasing the rate of nitrogen fertilizers increases the average fruit weight and volume of pepper. Data showed that $130 \mathrm{~kg} \mathrm{~N}$ $\mathrm{ha}^{-1}\left(\mathrm{~N}_{3}\right.$ treatment) had given highest number of fruits per plant that's why the total yield per hectare was increased greatly. This result is also in agreement with Ahmed et al. (2007). It was revealed that at optimum level nitrogen fertilizer gave highest yield plant $^{-1}$ and increase nitrogen fertilization delayed flowering. Jilani et al. (2008) reported that nitrogen application @ $100 \mathrm{~kg} \mathrm{ha-}{ }^{1}$ significantly increased brinjal yield. In the roof top garden, the highest yield obtained from $\mathrm{N}_{3}$ treatment which is 5.53 ton/ha. In field condition the average yield is around 8-10 ton but in rooftop garden the average yield production was low but very attractive. Likewise, Bahuguna et al. (2014) also observed the same results in pea. Nitrogen fertilization improved plant growth, but did not influence fruiting time. Jilani et al. (2008) reported that nitrogen application @ 110-130 kg ha- ${ }^{1}$ significantly increased brinjal yield. In pea, Bahuguna et al. (2014) also found the same results.

\section{Conclusion}

Considering the above mentioned results, it may be concluded that, different doses of nitrogen varied significantly for growth and yield of chili. The yield components and yield of chili were positively influenced by the application of nitrogen on rooftop garden. It was revealed that application of $130 \mathrm{~kg} \mathrm{~N} \mathrm{ha-}{ }^{1}$ produce maximum yield and yield contributing characters of chili in the rooftop garden. It can be suggest that growth and yield of chili may be increased by using nitrogen which create favourable climatic condition in soil environment at the roof top garden.

\section{References}

Ahmed N, Baloch MH, Haleem A, Ejaz M, Ahmed N. 2007. Effect of different levels of nitrogen on the growth and production of cucumber. Life Sci. Int. J., 1: 99-102.

Akanbi WB, Togun AO, Akinfasoye JO, Tairu FM. 2007. Physico-chemical properties of Eggplant (Solanum melongena L.). Fruit in response to nitrogen fertilizer and fruit size. Agri. J., 2: 140-148.

Aman F, Ishtiaq M. 2002. Effect of different levels of nitrogen and plant spacing on the growth and yield of sweet pepper cv. yellow wonder. Sarhad J. of Agri. Sci. 18(3): 275-279.
Aminifard MH, Aroiee H, Ameri A, Fatemi H. 2012. Effect of plant density and nitrogen fertilizer on growth, yield and fruit quality of sweet pepper (Capsicum annum L.). African J. of Agri. Res., 7(6): 859- 866.

Ayodele VI. 2002. Influence of nitrogen fertilisation on yield of Amaranthus species. J. Acta. Hort., 571: 89-95.

Awal MA, Ohta T, Matsumoto J, Toba T, Daikoku K, Hattori S, Hiyama T, Park H. 2010. Comparing the carbon sequestration capacity of temperate deciduous forests between urban and rural landscapes in central Japan. Urban Forestry and Urban Greening 9:261-270.

Bahuguna A, Singh B, Bahuguna S. 2014. Consequence of optimum levels of fertilizer on enlargement and yield of vegetable pea cv. VL ageti matar 7 under Uttarakhand hills condition, J. Agron., 13(3): 153-157.

Boroujerdnia M, Ansari N. 2007. Effect of different levels of nitrogen fertilizer and cultivars on growth, yield and yield components of romaine lettuce (Lactuca sativa L.). Middle Eastern and Russian J. Plant Sci. and Biotech. 1: 47-53.

Czemiel BJ. 2010. Green roof performance towards management of runoff water quantity and quality: A review. Ecological Engineering: the Journal of Ecotechnology', 36(4): 351-360.

Damke MM, Kawarkhe VJ, Patil CU. 1990. Effect of phosphorus and potassium on the growth and yield of chili, PKV Res. J., 12:110-114.

Gastal F, Lemaire G. 2002. Nitrogen uptake and distribution in crops: an agronomical and ecophysiological perspective. J. Exp. Bot. 53: 789-799.

Guohua XU, Kofkafi U. 2001. Interaction effect of nutrient concentration and container volume on flowering, fruiting and nutrient uptake of sweet pepper. J. Plant Nutri., 24(3): 479-501.

Gupta CR, Sangar SS. 2000. Response of tomato (Lycopersicon esculentum Mill.) to nitrogen and potassium fertilization in acidic soil of Bastar. Veg. Sci., 27(1): 94-95.

Islam MS, Ahmed R. 2011. Land Use Change Prediction in Dhaka City Using GIS Aided. 6: 81-89. Retrieved August 28, 2015.

Jilani, MS, Afzaal MF, Waseem K. 2008. Effect of different nitrogen levels on growth and yield of brinjal. J. Agric. Res., 46: 245-251.

Khurana DS, Rupinder S, Sidhu AS, Ranjodh S. 2006. Effect of different levels of nitrogen in split doses on growth and yield of chili. Indian J. of Hort., 63, pp 467-469.

Lal N, Pundrik KC. 1971. Effect of nitrogen, phosphorus and potassium on the growth and yield of chili. Punjab Hort. J., 11: $82-86$.

Lemaire G. 2001. Ecophysiology of grassland: Dynamic aspects of forage plant population in grazed swards. In Proceedings of the XIX International Grassland Congress, Brazil. pp. 2937.

Manchanda AK, Singh B. 1988. Effect of plant density and nitrogen on growth and fruit yield of bell paper. Indian $\mathrm{J}$. Agric., 33: 445-447.

Nagase A, Dunnett N. 2011. The relationship between percentage of organic matter in substrate and plant growth in extensive green roofs. Landscape and Urban Planning 103: 230-236.

Nicola S, Basoccu G, Tongoni F, Leoni S. 1995. Pretransplant nutritional conditioning affects pepper seedling growth and yield. International symposium on new cultivation systems in greenhouse, Cagliari, Italy, 26-30 April, 1993. Acta-Hort., 361: 519-526.

Rhodes CC, Eckert GE, Coleman DC. 2000. Soil carbon differences among forest, agriculture and secondary vegetation in lower montane Ecuador. Ecological Applications 10(2): 497-505.

Roy SS, Khan MSI, Pall KK. 2011. Nitrogen and phosphorus efficiency on the fruit size and yield of capsicum. J. Exp. Sci., 2(1): 32-37. 
Smit J, Ratta A, Nasr J. 2001. Urban agriculture: Food, jobs and sustainable cities. United Nations Development Programme, publication series for Habitat II, Vol. 1. New York: UNDP.

Taylor G, McDonald AJS, Stadenberg I, Freer-Smith PH. 1993.

Nitrate supply and the biophysics of leaf growth in Salix viminalis. J. Exp. Bot., 44: 155- 164.
Wardard Y. 2014. November 19. Rooftop gardening can meet Dhaka's 10pc of vegetable demand. Retrieved from the financial express-bd.com: (http://www.thefinancialexpressbd.com/2014/11/19/66659/print). 